DOI 10.37882/2223-2982.2020.11.22

\title{
ЯЗЫК И ЯЗЫКОВОЕ СОЗНАНИЕ В ЛИНГВОКОГНИТИВНОМ ИЗМЕРЕНИИ
}

\section{LANGUAGE AND LANGUAGE CONSCIOUSNESS IN THE LINGUO-COGNITIVE DIMENSION O. Litvyak}

Summary: The scientific article discusses the main theoretical issues to be related to the representation of language and linguistic consciousness in the linguo-cognitive dimension. There are studied the problems of the relationship between language, linguistic consciousness and linguistic personality in the linguistic and cultural aspects. The emphasis is placed on the ambivalent role of language in the development of linguistic consciousness. It is theoretically substantiated the relationship between language and linguistic consciousness as a problem of the implicit expression in the process of communicative interaction, and it is carried out a theoretical review of the research works of scientists to have dealing with this issue.

Keywords: representation, language, linguistic consciousness, linguocognitive dimension, linguistic personality, implicit expression, linguocultural aspect.
Литвяк Олеся Валерьевна

К.филол.н., доцент, ГБОУВО РК КИПУ имени Февзи Якубова,

2. Симферополь

ole.litviak@yandex.ru

Аннотация: В данной научной статье рассмотрены основные теоретические вопросы, связанные с репрезентацией языка и языкового сознания в лингвокогнитивном измерении. Изучаются проблемы соотношения языка, языкового сознания и языковой личности в лингвокультурологическом аспекте. Делается упор на амбивалентную роль языка в развитии языкового сознания. Теоретически обосновывается взаимосвязь языка и языкового сознания как проблема имплицитного выражения в процессе коммуникативного взаимодействия, а также проводится теоретический обзор научно-исследовательских трудов ученых, занимающихся данной проблематикой.

Ключевые слова: репрезентация, язык, языковое сознание, лингвокогнитивное измерение, языковая личность, имплицитное выражение, лингвокультурологический аспект.
Термин «языковое сознание» является абсолютно идентичным такому понятию, как «знаковая функция языковой единицы». В состав данного понятия обязательно должно входить изучение текущих реалий языка, которые могут компилировать данные во время процесса общения. Такая характерная черта репрезентирует как определенная взаимосвязь языка с когнитивным механизмом и его логикой и как уникальная черта, позволяющая обозначить огромное многообразие объективного мира. [5, с.9]

Процесс начала обучения лингвокогнитивных основ языка и языкового сознания в мировой науке было заложено Ф. де Соссюром. Именно ему принадлежит главенство в разработке полной теории языка. Проблема знаковости обычного языка порождает изучение вопросов, которые касаются его сущности, среди которых можно выделить:

- взаимосвязь языка, мышления и текущей действительности;

- структурное формирование языка как определенной знаковой системы;

- характерные черты знаков языка, а также их функциональность и разновидности;

- природу значения понятия язык и его разновидности. 
Ученый подчеркивает, что «язык - это форма разграничения и упорядочения мышления, имеющая хаотический характер, и лишь затем механизм объективации материального мира» [9, с.161]. Следовательно, он проводит абсолютизацию общественного характера языка, что служит базой для проведения дефиницирования сознания языка как «самого мышления, процесса абстрагирования от словесного выражения» с некой аморфной составляющей [9, с.162]. К примеру, всем известный человек разумный или, если использовать научный термин, «homo sapiens» может осуществить процесс онтологизации окружающего мира, что является характерной особенностью сознания его языка. В качестве основы знаковой репрезентации выступает взаимосвязь таких понятий, как языковое познание, язык и окружающий мир. Таким образом, она, фактически, выступает в качестве элемента «идеализации материального мира». Огромную роль в ее создании играет выбор определенной функции в качестве своеобразной нулевой точки, которая задается с целью определения языка, и выбор непосредственно языкового знака, который выступает в качестве элемента конвенциональной семиотической системы феномена, репрезентирующего естественный язык как знаковую систему особого рода [6, С.151-210].

Особую роль в рассмотренных выше понятиях принадлежит сигналам, которые несут коммуникационную и прагматическую функции в рамках специально созданных систем языка (к примеру, известная во всем мире азбука Морзе или дорожные сигналы). Помимо информационной функции, данные сигналы обязаны приводить к появлению реакции, целью которой является осуществления процедуры управления выбранной системы сигналов в языковом сознании индивидуума. Данные элементы опосредуют практические ситуации или действия, которые формируются языковым сознанием конкретно взятого человека. Первостепенной важностью обладает первая система сигналов, которая чаще всего свойственна животным, а также вторая система сигналов индивидуума, развивающаяся в процессе общения и отвлеченно отображая объективную реальность [5, с.13].

Коммуникативная функция, а также стилизация речи конкретного человека определяет взаимоотношения языка и языкового сознания. Процесс общения является возможным только в том случае, если в знаках языка и структурах знаков определяющим является результат работы языка в процессе общения, то есть когда язык будет выполнять такие функции, как коммуникативность, прагматичность, репрезентабельность и сигнифицированность.

В целом для языка является весьма характерным наличие двойной связи, выражающейся в синтагматических и парадигматических взаимоотношениях. А для языкового сознания свойственны такие взаимосвязи, как одинарная, парадигматическая, а также интерпретирующая его имплицитные смыслы.

Стоит отметить, что в системе языка значение единицы языка является виртуальным, то есть соотносится с определенным объектом. В.Н Комиссаров, как и Ч. Моррис [6], подчеркивает, что существует три базовых вида знаковых отношений, которые являются типичными для языка и языкового сознания. К их числу относятся:

- знак связан с тем, что обозначает (семантика знака);

- знак существует в системе и связан с другими знаками (синтактика знака);

- знак связан с людьми, употребляющими знак (прагматика знака). Три вида связи составляют значение знака [3, с.29]; [6, с.37-89].

В процессе общения знаки должны выполнять набор определенных функций, главными из которых выступают дескриптивная и креативная. Первая функция представляет собой процесс транслирования данных о внеязыковой деятельности, вторая функция - текущий уровень сложности в процессе декорирования транслируемых данных.

А.Н. Леонтьев отмечает, что значение языка представляет собой обобщенное отображение реальной действительности. [4, с.176]. С данным утверждение сложно не согласиться, потому что каждое значение становится актуальным при наличии таких связях с объектной действительностью, которые являются объективными и доказанными и принадлежат системам, которые описывают их онтогенез.

На современном этапе развития научного знания ученые, занимающиеся в данной сфере, практически всегда обращаются к национальным и культурным категориям сознания языка как с коллективной, так и с индивидуальной составляющей, в первую очередь, этнической расположенности. В данном случае язык выступает в качестве средства, которое используется для показа культурных тегов, и выступает в качестве элемента концептуального пространства, которое описывает внутреннюю когеренцию любого языка и сознания, а социума и человека. Языковое же сознание в данном случае изучается исходя из его онтологии за счет сравнения и сопоставления с характерными чертами как своей, так и чужой культуры. В данном случае наибольшую актуальность приобретает так называемый междисциплинарный подход, который дает возможность использовать методики и результаты, как лингвистики, так и других смежных с ней наук [5, с.25].

Как нам кажется, катехизис сознания языка каждой нации является не полностью исследованным. Большинство проблем носят гораздо более широкий характер. Л.В. Сахарный отмечает следующий необычный случай, 
который возник в догуманитарной лингвистике: «Изучая язык человека, наука о языке оказывается лингвистикой без человека» $[8$, с.6].

Процесс изучения сознания языка и его самого в целом не может быть произведен отдельно. Связь сознания языка с деятельностью индивидуума подтверждает наличие психологических аспектов, которые становятся актуальными во время общения и взаимной деятельности людей, а также во время выполнения ими коллективной работы. [10, с.22]. Следовательно, процесс изучения сознания языка может быть осуществлен только за счет синтеза психолингвистического и культурологического методов, которые широко распространены в лингвистике.

При проведении лингвокогнитивного измерения взаимоотношения языка, речи, сознания и мышления индивидуума используются в произвольных ситуациях взаимодействия с учетом необходимой специфики сознания в целом, которое выступает базовым механизмом, который используется в познавательном процессе культуры (как собственной, так и чужой) [5, с.45]. Сознание и язык находятся во взаимной связи - второй влияет на первое с помощью всевозможных лингвокультур. Стереобазисом в процессе развития сознания выступает диалогическая коммуникация - большинству людей дают возможность воспринимать как их вербализованные мысли, так и объективировать культурные смыслы. [7, с.134].

Сознание и язык являются амбивалентными по отношению к общей картине мира. [14, с.158]. Следовательно, речь и язык создают определенный языковой материал с использованием сознания.

Сознание находится в отдельном существовании от человека. Когда оно рождается, то происходит постепенный процесс его развития в границах ментальной культуры. Данное развитие происходит не как некая характерная биологическая предрасположенность, а как конечный результат взаимного воздействия с культурно обусловленной внешней средой. Главные факторы представляются в виде «идеальной формы существования факторов предметного мира, его свойств, связей и отношений, которая преобразована и упакована материей языка» [12, с.141].

На текущем уровне развития лингвистики больше всего внимания уделяется вопросам изучения влияния человеческого фактора в языке как некоей осознанной языковой деятельности. «Сознание в своей непосредственности есть открывающаяся субъекту картина мира, в которую включен он сам, его действия и состояния» [4, с.167].

Основываясь на современной теории лингвистики, можно сказать, что под языковым сознанием понимается объединение «образов сознания, формируемых и овнешняемых при помощи языковых средств - ассоциативных полей» [10, с.22]. В данном понятии соединяются две абсолютно противоположные сущности - сознание и физиологический процесс создания вербальных языковых взаимосвязей [13, с.17].

Под языковым сознанием понимается преобразование человеческой деятельности в форме вербализации социокультурного опыта личности и национально-культурного осознания такого опыта ею. Такой ракурс рассмотрения позволяет выделить в нем три основных компонента, которые получают актуализацию в процессе ментальной деятельности: материальное (языковое знание как материальный субстрат сознания), идеальное (психические состояния, семантика), социокультурный опыт (знания о мире) [5, с.95].

Итак, язык и языковое сознание в лингвокогнитивном измерении рассматриваются как языковые знаковые средства передачи информации в координатах значений, закрепленных за ними. Это способствует реализации различных коммуникативных и экспрессивных задач в процессе коммуникации. Ценность знака реляционно-объектная по своей природе, что позволяет воспринимать его как компонент языкового сознания индивида.

Соотношение между означающим и означаемым характеризуется определенной динамикой и может быть нарушено. Языку в лингвокультурном пространстве присуще идентифицировать предметы и явления, а также способствовать их узнаванию в процессе коммуникации.

Языковое сознание - идеальная экзистенция предметного мира. В индивидуальном сознании значения и смыслы различны сознанием конкретной «субъективной» личности.

Как «превращенная форма жизнедеятельности человека» [5, с.13] языковое сознание обуславливает социокультурный багаж знаний личности и его национальнокультурную принадлежность.

\section{ЛИТЕРАТУРА}

1. Арно, А. Логика, или Искусство мыслить / А. Арно, П. Николь. - 2-е изд. - М.: Наука, 1997. - 331 с.

2. Ахиджакова, М.П. Межкультурные основы в текстовом аспекте современной лингвистики / М.П. Ахиджакова // Вестник Адыгейского государственного университета. Сер. Филология и искусствоведение. - Майкоп: Изд-во АГУ, 2012. - Вып. 1. - С. 182-187. 
3. Комиссаров, В.Н. Современное переводоведение: учеб. пособие / В.Н. Комиссаров. - М.: ЭТС, 2002. - 424 с.

4. Леонтьев, А.Н. Деятельность. Сознание. Личность / А.Н. Леонтьев. - М.: Наука. 1975. - 167 с.

5. Литвяк, О.В. Ценностно-смысловое пространство художественного текста: лингвокогнитивное измерение: монография / 0.В. Литвяк, 0.П. Давыдова. Симферополь, ИТ «АРИАЛ», 2019. - 176 с.

6. Моррис, Ч. Основания теории знаков / Ч. Морис // Семиотика / сост. Ю.С. Степанов. - М.: Радуга, 1983. - С. 37—89.

7. Парандовский, Я. Алхимия слова / Я. Парандовский. - М.: Правда, 1992. - 401 с.

8. Сахарный, Л.В. Введение в психолингвистику / Л.В. Сахарный. - Л.: Изд-во ЛГУ, 1987. - 180 с.

9. Соссюр, Ф. де. Труды по языкознанию / Ф. де Соссюр. - М.: Наука, 1977. - 251 с

10. Тарасов, Е.Ф. Актуальные проблемы анализа языкового сознания / Е.Ф. Тарасов // Языковое сознание и образ мира: сб. ст. / отв. ред. Н.В. Уфимцева. M., 2000. - C. 19-24.

11. Тарасов, Е.Ф. Межкультурное общение - новая онтология анализа языкового сознания / Е.Ф. Тарасов // Этнокультурная специфика языкового сознания: сб. ст. / отв. ред. Н.В. Уфимцева. - М.: Эйдос, 1996. - С. 7-22.

12. Уорф, Б.Л. Грамматические категории / Б.Л. Уорф // Принципы типологического анализа языков различного строя. - М., 1972. - С. 44-60.

13. Ушакова, Т.Н. Языковое сознание и принципы его исследования / Т.Н. Ушакова // Языковое сознание и образ мира: сб. ст. / отв. ред. Н.В. Уфимцева. - М., 2000. - C. 13-19.

14. Щерба, Л.В. Языковая система и речевая деятельность / Л.В. Щерба. - Л.: Наука, Ленингр. отд. 1974. - 428 с.

( ) Литвяк Олеся Валерьевна (ole.litviak@yandex.ru).

Журнал «Современная наука: актуальные проблемы теории и практики»

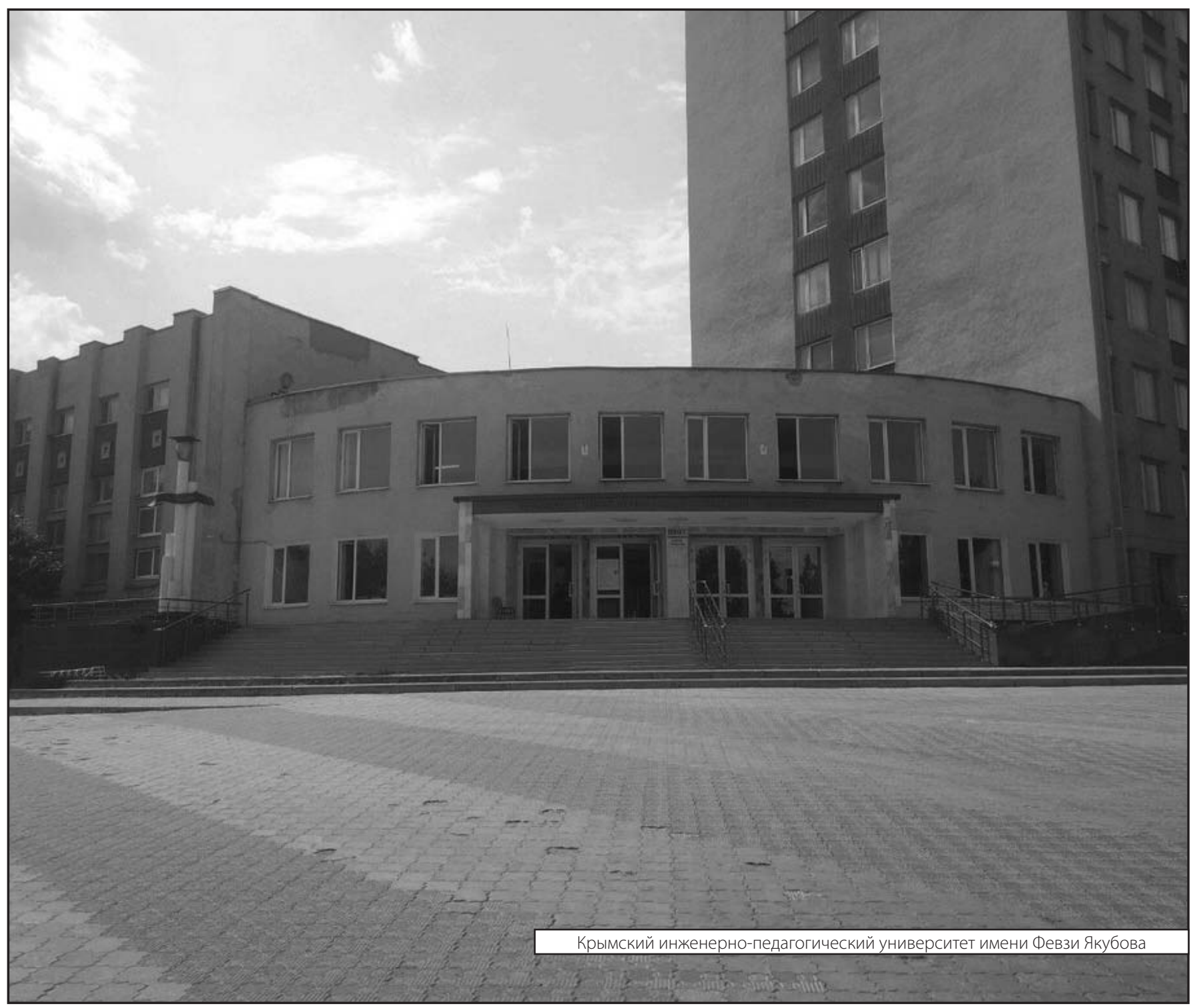

